\title{
Yfirfærsla á málaflokki fatlađs fólks frá ríki til sveitarfélaga: Međ sérstakri áherslu á stærsta sveitarfélagið, Reykjavík
}

\author{
Freydís Jóna Freysteinsdóttir, dósent við Félagsráđgjafardeild Háskóla \\ Íslands
}

Gylfi Jónsson, félagsráđgjafi hjá Barnavernd Reykjavíkur

\begin{abstract}
Útdráttur
Markmið rannsóknarinnar var að skoða hvernig yfirfærsla á málaflokki fatlaðs fólks frá ríki til sveitarfélaga hefði gengið fyrir sig. Heildarferli yfirfærslunnar var skoðað og síðan var eitt sveitarfélag, Reykjavíkurborg, valið og skoðað nánar með tilliti til stefnu og framkvæmdar á pjónustunni við fatlað fólk. Um var að ræða eigindlega rannsókn sem fór fram haustið 2012. Tekin voru átta viðtöl við fagaðila sem höfðu komið beint að vinnu við yfirfærsluna eða unnið við málaflokkinn fyrir og eftir yfirfærslu. Tekið var viðtal við starfsmenn hjá velferðarráðuneytinu og hjá Sambandi íslenskra sveitarfélaga. Pjónustumiðstöðvar Reykjavíkurborgar eru sex talsins, eitt viðtal var tekið á hverri pjónustumiðstöð og leitast var við að fá viðmælanda sem var hvað mest inni í málaflokknum. Helstu niðurstöður voru pær að viðmælendur töldu almennt séð rétt að ráðist skyldi hafa verið í yfirfærsluna. Peir töldu að pjónusta í nærsamfélaginu væri heppilegri kostur og nú pyrfti pjónustupeginn aðeins að fara á einn stað til pess að sækja sér pjónustu, jafnvel pó að ekki hefðu orðið eins miklar framfarir í pjónustunni og búist hefði verið við. Deir töldu pó að töluvert fjármagn vantaði í málaflokkinn til að tryggja viðeigandi pjónustu og að yfirfærslan hefði ekki verið nægilega vel undirbúin. Viðmælendur voru á pví að pverfagleg vinna gengi vel í málaflokknum.
\end{abstract}

Efnisorð: Fatlaðir; stjórnsýsla; breytingastjórnun; valdefling.

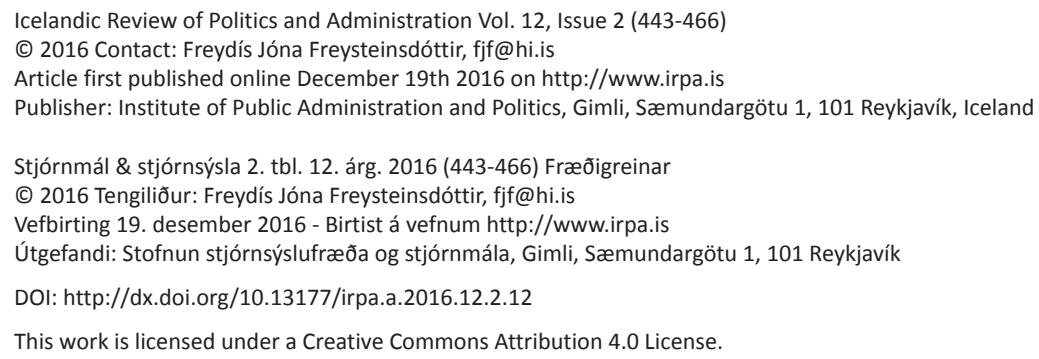




\title{
The transfer of disability affairs from the state to the municipalities: With special emphasis on the largest municipality, Reykjavík
}

\begin{abstract}
The aim of this study was to examine how the transfer of the affairs of disabled people from the state to the municipalities had proceeded. The process of the transfer was examined and then the largest municipality, Reykjavík, was chosen for a closer examination on the policy and implementation concerning services for disabled people. A qualitative study was conducted in the autumn of 2012. Eight interviews were taken with key professionals who had been involved directly in the transfer or worked on the affairs of disabled people before or after the transfer. A specialist in the affairs of disabled people was interviewed at the Ministry of Welfare and at the Association of Local Authorities in Iceland. Furthermore, a key professional was interviewed in each of the six municipal services in Reykjavík. The interviewees believed that having decided on and gone through with the transfer was the right thing to do. They believed that services closer to the people who need it would be a better choice. The person that uses the services only needs to go to one place in order to receive it, instead of two as before. However, the interviewees had not seen a considerable improvement in the services as expected. Considerable additional funds are needed for the affair. The transition from the state to the municipalities was not sufficiently prepared. The affairs of disabled people requires a lot of interdisciplinary work as well, which the interviewees thought was proceeding well.
\end{abstract}

Keywords: disabled people; administration; management changes; empowerment.

\section{Inngangur}

Málaflokkur fatlaðs fólks á sér ekki ýkja langa sögu í löggjöf landsins, pó að gera megi ráð fyrir að fólk hafi búið við ýmiss konar fötlun frá ómunatíð. Fyrstu lögin tóku gildi á fyrri hluta síðustu aldar, lög um fávitahæli nr. 18/1936 og fylgdu peim fremur fábrotin úrræði í málaflokknum. Lagaumhverfið hefur próast síðan pá með fjölbreyttari úrræðum og auknum réttindum fyrir fatlað fólk. Pessi úrræði höfðu verið að mestu í höndum ríkisins eins og endurspeglaðist í lögum um málefni fatlaðra nr. 41/1983, fyrir utan einstaka pjónustusamninga sem ríkið hafði gert við fáein sveitarfélög, pegar málaflokkurinn var yfirfærður frá ríki til sveitarfélaga (Norðurping, e.d.; Óskar Dýrmundur Ólafsson, 2011). Hugmyndafræðin sem lá að baki pessari yfirfærslu var meðal annars sú að betra væri að pjónusta við fatlað fólk væri á einu stjórnsýslustigi (Velferðarráðuneytið e.d.-a) og í nærumhverfi pjónustupega (Gunnar Helgi Kristinsson 2001). Talið var líklegt að pjónusta í nærumhverfi pjónustupega myndi gera pað að verkum að pjónustupegar hefðu meira um pjónustuna að segja og að hún virkaði pví valdeflandi fyrir pá (Beresford \& Croft 2000). 
Í pessari rannsókn var skoðuð reynsla af yfirfærslu á málaflokki fatlaðs fólks frá ríki til sveitarfélaga sem átti sér stað pann 1. janúar 2011. Pessi breyting er sennilega sú stærsta sem orðið hefur í málaflokki fatlaðs fólks síðustu ár ef ekki áratugi. Kannað var hvernig undirbúningi var háttað, hvað ávannst við yfirfærsluna fyrir pjónustupega og starfsfólk og hvað hefði betur mátt fara. Jafnframt var könnuð sýn lykilstarfsmanna innan tveggja ríkisstofnana sem koma að pessum málaflokki á landsvísu og starfsfólks innan pjónustumiðstöðvanna sex í Reykjavík á yfirfærsluna, en petta var fólk sem hafði hvað mest unnið í pessum málaflokki eftir að breytingin átti sér stað.

\section{Söguleg próun laga og umfang málaflokksins}

Löggjöf og mótun yfirvalda hverju sinni á stefnu í málefnum hinna ýmsu hópa hefur, eðli málsins samkvæmt, töluverð áhrif á pað hvernig peim hópum getur vegnað á hverjum tíma. Stefna yfirvalda í málefnum fatlaðs fólks ræður pví miklu um pau lífsgæði sem fatlaðir búa við. Stefnumörkunin byggist á viðhorfum til málefnisins hverju sinni. Viðhorf gagnvart fötluðum hafa breyst mikið í gegnum tíðina. Rökrétt er að áætla að ýmis konar fötlun hafi fylgt mannkyninu frá fyrstu tíð. Fyrr á öldum var peim einstaklingum sem póttu á einhvern hátt afbrigðilegir oft útskúfað úr samfélaginu. Fötluð börn voru jafnvel myrt vegna fötlunar sinnar, til dæmis tíðkaðist pað hjá Spartverjum að fara með öll börn til eftirlitsráðs ríkisins og ef barnið leit út fyrir að vera fatlað var pví kastað fyrir björg (Margrét Margeirsdóttir 2001).

Fyrstu lögin sem sneru að fötluðum voru sampykkt á Alpingi árið 1936 en pað voru lög um fávitahæli. Lög pessi áttu að tryggja stofnun skólaheimilis fyrir vanvita og hálfvita, eins og pað var orðað í lögunum. Einnig skyldi stofnað hjúkrunarhæli fyrir örvita og fávita sem ekki hefðu tök á að nýta sér námið á skólaheimilinu og par að auki átti að setja á fót vinnuhæli fyrir fullorðna fávita sem gátu unnið einhver störf en pó ekki störf á almennum vinnumarkaði. Að auki var tiltekið í lögum pessum að veita skyldi fávitum framfærslustyrk sem væri ekki skilgreindur sem fátækrastyrkur eins og verið hafði fram að pví (Margrét Margeirsdóttir, 2001). Næstu lög í málaflokknum, sem tóku við af lögum um fávitahæli, voru lög um fávitastofnanir nr. 53/1967. Með peim lögum, sem tóku gildi árið 1967, varð Kópavogshæli, sem hafði starfað frá árinu 1952, aðalhælið fyrir fávita og voru pegar mest var um 200 manns vistaðir par. Баð var á áttunda áratug síðustu aldar og fór vistmönnum smám saman fækkandi eftir pað, flestir peirra fluttu á sambýli (Margrét Margeirsdóttir 2001).

Næst voru sett lög um aðstoð við proskahefta nr. 47/1979. Pau lög endurspegla breytta hugmyndafræði. Í peim er hugtakið proskaheftir notað yfir pá sem eru með skerta greind í stað fávita áður og var markmið laganna að tryggja peim sömu réttindi og öðru fólki. Jafnframt stóðu proskahömluðum mun fleiri úrræði til boða með peim lögum. Má par nefna leikfangasöfn og afpreyingarheimili. Kveðið er á um að veita skuli sérfræðipjónustu á hverju svæði í peim lögum, svo sem proskapjálfun, félagsráðgjöf og sálfræðipjónustu. Fleiri nýjungar í úrræðum litu dagsins ljós með lögum um málefni fatlaðra frá 1983. Má par nefna hjálpartækjapjónustu og flutningspjónustu eða ferðapjónustu fatlaðs fólks. 
Núgildandi lög eru lög um málefni fatlaðra nr. 59/1992 með áorðnum breytingum. Í peim kemur fram að hafa skuli fatlað fólk sem pjónustupega með í ráðum eða fulltrúa pjónustupega, eins og til dæmis fulltrúa Öryrkjabandalags Íslands (ÖBÍ) og Proskahjálpar. Petta samræmist peirri stefnu sem kemur meðal annars fram í ályktun Sjálfsbjargar, par sem petta er orðað á eftirfarandi hátt: „Ekkert um okkur án okkar“ (Sjálfsbjörg e.d.-a). Með breytingum á lögum um málefni fatlaðra nr. 152/2010 er farið að nota hugtakið „,fatlað fólk“ í staðinn fyrir orðið „fatlaðir“. Hugmyndafræðin á bak við pessi lög endurspeglar nokkra viðhorfsbreytingu gagnvart fötluðu fólki og hnykkir enn frekar á réttindum pess til sambærilegs lífs og ófatlaðs fólks.

Með pví að skoða pessi gömlu lög og viðhorf til fatlaðs fólks frá fyrstu tíð sést hversu mikið hefur breyst í pessum efnum. Allt annað tungutak er notað nú til dags og margt af pví sem notað var í eldri textum pætti óviðunandi nú. Фað sýnir að pað sem gert er í dag og pykir rétt, parf alls ekki að vera viðeigandi á morgun. Textinn um fávita og vanvita er áminning um að málefni fatlaðs fólks séu og verði að vera í stöðugri frampróun og taka breytingum í takt við pjóðfélagið hverju sinni. Í nýjustu lögunum um málefni fatlaðra er aukin áhersla á samráð við pjónustupega og að peir taki sjálfir ákvarðanir er tengjast peim, hafi peir hæfni til pess. Slíkt samráð var áður tilgreint í lögum um aðstoð við proskahefta og í lögum um málefni fatlaðra frá 1984. Áhersla á samráð hefur farið vaxandi, en áður fyrr var viðhorfið gjarnan pað að fagfólkið vissi betur. Pessari próun ber að fagna. Líklegt er að í pessum málaflokki, sem og öðrum, verði petta meginútgangspunktur í stórum ákvörðunum er varða pjónustu við tiltekna hópa í samfélaginu.

Markmið núgildandi laga um málefni fatlaðra er að tryggja fötluðum einstaklingum jafnrétti og sambærileg lífskjör á við aðra pjóðfélagspegna og skapa peim nauðsynleg skilyrði til pess að fatlað fólk geti lifað eðlilegu lífi. Einnig er tiltekið í markmiðum laganna að samtökum og aðildarfélögum fatlaðs fólks skuli tryggt áhrifavald varðandi stefnumörkun og ákvarðanir um málefni pess.

pessi markmið líta vel út á prenti en hins vegar er ekki skilgreint í lögum um málefni fatlaðra hvað sé eðlilegt líf og hvað séu sambærileg lifskjör. Útfærsla á pessum markmiðum er pví að einhverju leyti huglæg og í hendi peirra sem stjórna hverju sinni. Staða og aðstæður tveggja einstaklinga sem báðir eru taldir fatlaðir geta verið mjög mismunandi. Engu að síður parf að ákveða í hvoru tilviki fyrir sig hvort einstaklingur skuli vera skilgreindur fatlaður.

Á heimasíðu Tryggingastofnunar (e.d.) má sjá að Íslendingar sem metnir eru 75\% öryrkjar eru tæplega 17.000 talsins. En ekki eiga allir öryrkjar við fötlun að stríða, pað er í merkingu laga um málefni fatlaðs fólks, eins og vikið verður að hér á eftir. Undir pá pjónustu sem lög um málefni fatlaðra taka til falla peir sem eru andlega eða líkamlega fatlaðir og parfnast sérstakrar pjónustu vegna peirrar fötlunar. Fötlun getur samkvæmt lögum um málefni fatlaðra falist í proskahömlun, geðfötlun, hreyfihömlun, sjón-og heyrnarskerðingu eða komið til í kjölfar veikinda eða slysa. Sjálfsbjörg, landssamband fatlaðra hefur um 2.000 félagsmenn (Sjálfsbjörg e.d.-b) en fatlaðir einstaklingar 18 ára og eldri eru rétt rúmlega 2.000 talsins og börn sem ríkið greiðir umönnunarbætur með vegna fötlunar peirra eru rúmlega 1.500 talsins (Hagfræðistofnun e.d.). 


\section{STJÓRNMÁL \& \\ STJÓRNSÝSLA}

\section{Aðdragandi, markmið og hugmyndafræði á bak við yfirfærsluna}

pjónusta sem veitt er svo stórum hópi færist ekki á milli ríkis og sveitarfélaga án pess að um pað fari fram umræða og mikil skipulagsvinna. Fyrstu skrefin á Alpingi voru tekin árið 1996 eða heilum fimmtán árum áður en málaflokkurinn færðist svo á endanum yfir til sveitarfélaganna. Pegar sampykkt hafði verið að breyta gildandi lögum um málefni fatlaðs fólks var félagsmálaráðherra falið að undirbúa yfirfærsluna. Meginmarkmiðin með yfirfærslunni voru pau að færa pjónustuna nær pjónustupegum (Ómar H. Kristmundsson 2003), að bæta samhæfingu og draga úr skörun á milli stjórnsýslustiga (Velferðarráðuneytið e.d.-a) en nánar verður farið í markmiðin með yfirfærslunni síðar. Á næstu árum fór mikill tími og undirbúningur í yfirfærsluna, en prátt fyrir pað tókust ekki samningar á milli ríkis og sveitarfélaga og fór málið pví í vissa biðstöðu (Innanríkisráðuneytið e.d.). Á pessum árum var ríkisstjórn Sjálfstæðisflokks og Framsóknarflokks við völd og var Páll Pétursson félagsmálaráoherra, en hann gegndi pví embætti frá árinu 1995-2003 (Alpingi e.d.-d). Málið var síðan endurvakið árið 2007 og pá að frumkvæði Sambands íslenskra sveitarfélaga. Í apríl pað ár var svo skipuð sérstök verkefnisstjórn sem fékk pað hlutverk að undirbúa yfirfærsluna. Tæplega tveimur árum seinna, eða 13. mars árið 2009, var skrifað undir samkomulag á milli Sambands íslenskra sveitarfélaga og ríkisstjórnar Íslands um að málaflokkurinn myndi færast yfir til sveitarfélaga pann 1. janúar árið 2011. Pá var eftir að semja um fjárhagsramma yfirfærslunnar. Nokkru seinna var komið endanlegt samkomulag á milli aðila og var pað undirritað 23. nóvember, 2010. Pá var einungis eftir að sampykkja nauðsynlegar lagabreytingar á Alpingi svo að yfirfærslan gæti orðið og var pað gert í desember sama ár (Innanríkisráðuneytið e.d.).

Á pessum árum var töluvert umrót í íslenskum stjórnmálum og bví nokkrir ráðherrar sem komu að málinu. Á árunum 2007-2009 gegndi Jóhanna Sigurðardóttir embætti félagsmálaráðherra pegar Samfylking og Sjálfstæðisflokkur voru í ríkisstjórn (Alpingi, e.d.-c). Pegar Jóhanna tók við sem forsætisráðherra varð Árni Páll Árnason félagsmálaráðherra í ríkisstjórn Samfylkingar og Vinstri grænna (Alpingi e.d.-a) og að lokum var pað Guðbjartur Hannesson sem vann að yfirfærslunni sem velferðarráðherra fyrir hönd ríkisstjórnar Samfylkingar og Vinstri grænna (Alpingi e.d.-b). Halldór Halldórsson var endurkjörinn formaður Sambands íslenskra sveitarfélaga árið 2010 til fjögurra ára. Hann skrifaði pví undir yfirfærsluna fyrir hönd Sambands íslenskra sveitarfélaga (Samband íslenskra sveitarfélaga e.d.-b).

Árið 1991 var skipuð sveitarfélaganefnd og eftir að hún skilaði inn tillögum sínum til félagsmálaráðherra voru sampykkt lög um reynslusveitarfélög nr. 82/1994. Með peim lögum voru yfirvöld komin með pann sveigjanleika og umboð sem pau purftu til að gera breytingar og geta hafið yfirfærslu verkefna. Sú ákvörðun að hefja yfirfærslu hinna ýmsu verkefna frá ríki til sveitarfélaga er talin hafa stuðlað að próun og nýsköpun hjá sveitarfélögum (Óskar Dýrmundur Ólafsson 2011). Мeð pessum breytingum var hafin áxtlun sem fól í sér nýja stefnu í ríkisrekstri; sú stefna byggðist á dreifistýringu og hugmyndin var að geta fært verkefni á borð við velferðarpjónustuna nær notendum hennar (Ómar H. Kristmundsson 2003). Parna kemur fram að hugmyndin sé að fylgja hinni svokölluðu skandinavísku leið, en með pví er átt við að allir pegnar landsins njóti víðtækra velferðar- 
réttinda og almannatryggingakerfið sé notað til að jafna tekjur og lífskjaraskiptingu og fjármagnið komi frá skatttekjum ríkisins (Stefán Ólafsson 1999). Í slíkum velferðarríkjum eru 70\% verkefna hins opinbera á ábyrgð sveitarfélaga en ekki ríkis (Larsen, 2002). Skipan mála er í raun á pann veg að ríkið og ping móta stefnu og regluverk utan um málaflokka, en pað er svo á hendi sveitarfélaga að framkvæma pá stefnu í viðeigandi málaflokkum (Christiansen, Petersen, Edling \& Haave 2005).

Eitt af álitamálunum sem tengjast pví hvort málaflokkum sé betur varið hjá ríki eða sveitarfélögum er fjárhagsleg hagkvæmni og skilvirkni rekstrareininga eftir stærð. Um petta er hægt að deila, en Gunnar Helgi Kristinsson (2001) telur að hægt sé að auka hagkvæmni verkefna á borð við almenningssamgöngur, raforkuframleiðslu og önnur fjárfrek verkefni sem ekki kalla á mikið vinnuafl með pví að hafa pau í stórum einingum. Aftur á móti sýni pjónusta sem krefst mikils mannskaps, eins og umönnun og félagspjónusta, ekki aukna hagkvæmni í stórum einingum. Að mati Larsen (2003) borgar sig að brjóta pjónustusvæði í stórum borgum upp í minni pjónustusvæði. Með pví telur hann að pátttaka borgara verði meiri og félagsauður aukist. Heppileg stærð slíkra pjónustusvæða væri á bilinu 10 til 30 púsund manns. Rannsókn sem gerð var í nokkrum borgun á Norðurlöndum styður petta að mati Larsen (2003). Par var íbúafjöldinn allt frá tæplega 5.000 manns og upp í tæplega 65.000 manns. Niðurstöður sýndu að ekki væri fylgni milli stærðarmunar og skilvirkni, en pegar kom að pví að mæla ánægju fólks með pjónustuna var hún meiri í smærri einingum ásamt pví að lýðræðisleg pátttaka var meiri. Degar pjónustan var hverfaskipt í smærri einingar gekk pverfaglegt samstarf pjónustuaðila betur. Раð starf gekk best pegar íbúar kusu beint inn í hverfisráð og eftir pví sem völd notenda voru meiri yfir eigin pjónustu voru peir ánægðari með pjónustuna (Bäck, Gjelstrup, Helgesen, Johansson \& Klausen 2005).

Allar skipulagsheildir, ekki aðeins fyrirtæki, purfa að vera tilbúnar til pess að gangast undir breytingar ef pær ætla að eiga framtíð fyrir sér. Petta er nauðsynlegt par sem umhverfið er sífellt að breytast. Umhverfið kallar á breytingar en breytingar leiða ekki endilega allar af sér aðlögun (Herold \& Fedor 2008). Til pess að reyna að tryggja að aðlögun verði varanleg er mikilvægt að hafa skýra stefnu og markmið með peim breytingum sem ráðast á í. Kotter (1996) setti fram kenningu um pað hvernig haga ætti breytingum. Kenning hans gengur út á pað að breytingar skuli fara fram 1 átta skrefum og að pau purfi að vera í tiltekinni röð: A) Breytingarnar purfa að vera nauðsynlegar og pær purfa að vera til batnaðar fyrir alla sem koma að málinu. Pannig ætti að skapast samstaða um breytingarnar og flestir innan hópsins að vera áfram um pær. B) Safnað er saman hópi lykilstarfsmanna til pess að vinna að breytingunum. Traust og pverfagleg vinna fer fram par sem markmið eru skýr og aðrir eru upplýstir um stöðu mála. Lykilstarfsmenn purfa að vera áreiðanlegir, með breiða sérfræðipekkingu og hafa góða leiðtogahæfileika. C) Framtíðarsýn er próuð og kynnt starfsfólki. Đað eykur líkur á að breytingarnar gangi vel og og að starfsfólk sé tilbúið til að færa fórnir pegar breytingarnar síðan verða. D) Framtíðarsýn er kynnt á einfaldan og myndrænan hátt par sem pað á við. Halda ber smáa og stóra fundi með hópnum og nota tilkynningar í dagblöðum. Endurtaka skal upplýsingar svo fólk muni pær betur. E) Starfsmenn eru efldir til samstöðu. Reynt er að forðast að andstaða skapist gagnvart 


\section{STJÓRNMÁL \& \\ STJÓRNSÝSLA}

breytingunum, til dæmis með pví að gæta pess að allir starfsmenn hafi hlutverki að gegna í breytingaferlinu og að veita pví pjálfun. F) Áfangasigrum er fagnað með reglulegu millibili til að styrkja fólk í breytingavinnunni. Pannig sér fólk réttlætingu peirra fórna sem pað hefur fært. Áfangasigrar gagnast við að stilla stefnuna af og skerpa framtíðarsýnina, auk pess sem peir draga úr neikvæðum röddum og ósætti við breytingarnar. G) Áframhaldandi breytingar eru nauðsynlegar að loknum áfangasigrum. Hætta skapast á ákveðinni stöðnun í kjölfar peirra og pví er mikilvægt að nota hreyfiafl peirra. Hugsanlega gæti purft að bæta við mannskap til að hafa forystu um breytingastjórnunina. H) Breytingarnar eru festar í sessi. Ьað gerist pegar breytingum er að fullu lokið og fólk finnur sér nýjan stað eftir breytingarnar. Nauðsynlegt getur verið að skipta um lykilstarfsfólk til pess að festa breytingarnar í sessi og skapa nýja vinnumenningu.

pegar ráðist er í jafn stóra framkvæmd og yfirfærslu málefna fatlaðra frá ríki til sveitarfélaga purfa markmiðin að vera skýr og hugmyndafræðileg rök purfa að liggja til grundvallar yfirfærslunni. Helstu markmiðin með yfirfærslu málefna fatlaðs fólks frá ríki til sveitarfélaga eru rakin á vef velferðarráðuneytisins með eftirfarandi hætti:

Helstu markmið felast í pví að tryggja að eitt stjórnsýslustig beri faglega og fjárhagslega ábyrgð á stærstum hluta almennrar félagspjónustu, bæta samhæfingu og draga úr skörun ábyrgðar milli stjórnsýslustiga, styrkja sveitarstjórnarstigið og einfalda verkaskiptingu ríkis og sveitarfélaga og auka möguleika á pví að laga pjónustuna að pörfum notenda með hliðsjón af ólíkum aðstæðum.

(Velferðarráðuneytið, e.d.-a)

Hugmyndafræðin er pví sú að sé pjónustan veitt í grenndarsamfélaginu sé hún nær notendum hennar og pað sé til pess fallið að auka lýðræði og efla pátttöku íbúa í ákvörðunum um sín eigin mál. Hugmyndir eru einnig uppi um að sveitarfélögin geti sinnt heildstæðri nálgun við íbúa sína af meiri hagkvæmni en ríkið. Pegar rætt er um heildstæða nálgun er átt við að sveitarfélagið veiti sömu einstaklingum mismunandi pjónustu eftir ólíkum pjónustupörfum peirra (Gunnar Helgi Kristinsson 2001).

Í heildarsamkomulaginu eru markmiðin með yfirfærslunni tiltekin nákvæmlega og eru pau eftirfarandi: a) bæta pjónustu og auka möguleika til að laga hana að pörfum notenda með hliðsjón af ólíkum aðstæðum, b) stuðla að sampættingu nærpjónustu við íbúa sveitarfélaga, c) tryggja að eitt stjórnsýslustig beri ábyrgð á stærstum hluta almennrar félagspjónustu d) tryggja góða nýtingu fjármuna, e) styrkja sveitarstjórnarstigið, og að lokum f) einfalda verkaskiptingu ríkis og sveitarfélaga (Samband íslenskra sveitarfélaga, e.d.-a). Мeð peirri hugmyndafræði sem lýst var hér ætti að vera hægt að ná pessum markmiðum fram með skipulagðari vinnu. Hugmyndafræði sem snýr beint að vinnu með einstaklingum er til dæmis hugmyndafræði valdeflingar.

Valdefling er mikilvægt hugtak í vinnu við að byggja fólk upp og aðstoða pað við að taka ábyrgð og stjórna eigin lífi. Pegar völdin eru færð frá ríki til sveitarfélaga færast pau nær notendum pjónustunnar og pannig aukast líkurnar á að pjónustupegar hafi eitthvað 
um pjónustuna að segja. Pannig er stuðlað að valdeflingu peirra sem purfa á pjónustu að halda. Valdefling hefur meðal annars verið skilgreind pannig að sjálfstæði einstaklings sé eflt með pví að hvetja hann til að taka stjórnina í lífi sínu. Með pví upplifir viðkomandi að hann geti tekið meiri pátt í samfélaginu og orðið pátttakandi í ákvarðanatöku um mikilvæga pætti og pjónustu í lífi sínu fremur en eingöngu piggjandi (Beresford \& Croft 2000). Рað er pví mikilvægt að pjónustupegar og íbúar hafi sitt að segja um pað hvaða pjónustu skuli veita og hvernig hún skuli veitt (Bason 2010). Að valdefla pjónustupega er pví ekki beinlínis inngrip frá fagfólki heldur fremur lífssýn. Einnig getur petta orðið pólitísk áskorun og getur breytt aðferðum sem notaðar eru við að veita pjónustu, ásamt pví að breyta stjórnsýslunni (Beresford \& Croft 2000).

\section{3. Úrræđi î málaflokknum af hálfu hins opinbera og pjónustusvæđi}

Stoðpjónustunni sem ber að veita fötluðum af hálfu sveitarfélaga, samkvæmt lögum um málefni fatlaðra, er skipt í nokkra flokka eftir peim pörfum sem aðstoða parf við: A) Dörfin fyrir pjónustu sem fatlað fólk parf til pess að geta haft sjálfstætt heimilishald. B) Dörfin fyrir hæfingu, endurhæfingu og atvinnu til pess að viðkomandi geti séð sér farborða og tekið virkan pátt í samfélaginu. C) Dörfin fyrir félagslega ráđgjöf, sálfræðipjónustu, stuðning og félagslegt samneyti. Í pví felast einnig tómstundir og menningarlíf. D) Бörf fatlaðra barna fyrir umönnun og pjálfun og sú nauðsynlega aðstoð sem fjölskyldur peirra purfa til að geta veitt börnunum örugg og proskavænleg skilyrði. Allar pessar sértæku parfir ber sveitarfélögum að koma til móts við, samkvæmt lögum um málefni fatlaðra, með pjónustustöðvum. Бær eiga að vera starfræktar á hverju pjónustusvæði eftir pví sem pörf er á og ættu að vera eftirfarandi: Hæfingar-og endurhæfingarstöðvar, dagvistarstofnanir, verndaðir vinnustaðir og skammtímavistun. Húsnæðisúrræði fyrir fatlaða eiga að vera í íbúðabyggð og leitast skal við að hafa húsnæðið í nálægð við almenna og opinbera pjónustu. Sveitarfélögin eiga að útvega pessa pjónustu og skulu gera húsaleigusamninga við einstaklinga og innheimta af peim húsaleigu.

Samkvæmt lögum um málefni fatlaðra eiga börn á leikskólaaldri sem glíma við fötlun rétt á leikskóladvöl á vegum sveitarfélaga. Leikskóladvölin skal veitt á almennum leikskóla og á barnið rétt á nauðsynlegri stuðningspjónustu. Álag getur fylgt pví að hafa fatlað barn inni á heimili og af peim sökum skulu fjölskyldur fatlaðra barna eiga kost á ýmsum stuðningsúrræðum fyrir sig og barn sitt. Fjölskyldurnar skulu eiga rétt á stuðningsfjölskyldu eftir pví sem pörf krefur og foreldrar eiga rétt á skammtímavistun fyrir fötluð börn sín, en hún er hugsuð til pess að veita fötluðum einstaklingum tímabundna dvöl til pess að hvílast vegna erfiðra heimilisaðstæðna, veikinda eða annars álags. Einnig skal stuðlað að pví að fötluð börn eigi kost á sumardvöl pegar pörf er á og er hugmyndin á bak við pað að gefa peim möguleika á að skipta um umhverfi frá heimili sínu, sér til ánægju og tilbreytingar. Sveitarfélögunum ber einnig að veita fötluðu fólki liðveislu og frekari liðveislu ef purfa pykir. Liðveislan er hugsuð til að brjótast út úr eða koma í veg fyrir félagslega einangrun og styðja viðkomandi persónulega en frekari liðveisla snýr að pví að veita hinum fatlaða aðstoð heima við og aðra aðstoð sem miðar að pví að hann geti búið heima en pyrfti að öðrum kosti að dvelja á stofnun. 


\section{STJÓRNMÁL \& \\ STJÓRNSÝSLA}

Samkvæmt sömu lögum hefur félagsleg hæfing og endurhæfing fatlaðs fólks pað að markmiði að draga úr áhrifum fötlunar og auka hæfni pess til að starfa og auka pátttöku pess og virkni í daglegu lífi. Pessu er reynt að ná fram með sérstökum hæfingar- og endurhæfingarstöðvum, par sem fram fer proskapjálfun, iðjupjálfun og starfspjálfun. Аð auki á iðju- og starfspjálfun að fara fram á vernduðum vinnustöðum sem viðkomandi sveitarfélag býður upp á, en á hverju starfssvæði skal fötluðu fólki standa til boða vinna á vernduðum vinnustað. Við hæfingu eða endurhæfingu fatlaðs fólks er heimilt að veita styrki til verkfæra- og/eða tækjakaupa eða sjálfstæðrar starfsemi. Einnig er heimilt að veita styrki til greiðslu námskostnaðar sem ekki væri greiddur samkvæmt ákvæðum annarra laga. Eðli málsins samkvæmt getur ferðamáti fatlaðs fólks verið flóknari en peirra sem glíma ekki við fötlun. Af pessum sökum er tiltekið í lögum um málefni fatlaðra að sveitarfélögin skuli gefa fötluðu fólki kost á ferðapjónustu. Markmið með ferðapjónustu fatlaðs fólks er að gera peim sem geta ekki notað almenningssamgöngur vegna fötlunar sinnar mögulegt að stunda atvinnu, nám og tómstundir. Jafnframt má geta pess að fram kemur í lögum um félagspjónustu sveitarfélaga nr. 40/1991 að sveitarfélög skuli sjá um félagslega heimapjónustu fyrir pá einstaklinga sem ekki geta séð um heimilishald og persónulega umhirðu sjálfir vegna skertrar getu, sem getur verið tilkomin meðal annars vegna fötlunar.

Sveitarfélögin á Íslandi voru 74 talsins pegar yfirfærslan fór fram og misfjölmenn. Í desember 2010, pegar yfirfærslan var að koma til framkvæmda, var Reykjavík peirra stærst með 118.326 íbúa en Árneshreppur var minnst með einungis 50 íbúa (Samband íslenskra sveitarfélaga, e.d.-c). Í lögum um málefni fatlaðra er kveðið á um að sé íbúafjöldi sveitarfélags undir 8.000 geti sveitarfélög gert samning sín á milli um að veita fötluðum íbúum sínum pá pjónustu sem peim er skylt að veita sameiginlega. Í 69 sveitarfélögum á Íslandi voru færri en 8.000 íbúar. Баð voru eingöngu Reykjavík (118.326), Kópavogsbær (30.357), Hafnarfjarðarkaupstaður (25.913), Akureyrarkaupstaður (17.573), Reykjanesbær (14.091) og Garðabær (10.643) sem voru með fleiri en 8.000 íbúa pegar yfirfærslan fór fram (Samband íslenskra sveitarfélaga, e.d.-c). Petta pýðir að 92\% sveitarfélaga á Íslandi voru undir pessari 8.000 íbúa viðmiðunartölu. Af pessu sést að mörg sveitarfélög purftu að taka höndum saman um pjónustu við fatlaða (Samband íslenskra sveitarfélaga, e.d.-d). †ó voru dæmi um að sveitarfélög hefðu pegar gert pað og tekið við málaflokknum með pjónustusamningi við ríkið. Má par nefna að Húsavíkurbær tók við pjónustu við fólk með fötlun frá ríkinu með pjónustusamningi árið 1997 sem fluttist ári síðar til Héraðsnefndar Pingeyinga (Norðurping, e.d.), en að peim samningi stóðu nokkur sveitarfélög. Eftir að sveitarfélögin höfðu samið sín á milli um pjónustu reyndust einingarnar eða pjónustusvæðin vera 15 talsins. Af peim voru einungis fjögur sem héldu ein og sér utan um pjónustu sína. Önnur sveitarfélög stóðu saman að pjónustu. Sjá má hvaða sveitarfélög stóðu ein að pjónustu við fatlaða og hver stóðu saman að slíkri pjónustu eða keyptu pjónustu af öðru sveitarfélagi pegar yfirfærslan fór fram í töflu 1 . Af pessum 15 pjónustusvæðum voru fjögur sem ekki náðu 8.000 íbúa viðmiðinu og sóttu pví um undanpágu til ráðuneytisins á grundvelli fámennis á stóru landssvæði. petta voru pjónustusvæði Vestfjarða, pjónustusvæði Norðaustur- 
lands, Vestmannaeyjabær og Sveitarfélagið Hornafjörður (Samband íslenskra sveitarfélaga, e.d.-d).

Í töflu 1 má sjá að mörg sveitarfélög hafa purft að mynda samstarf um að sinna pjónustu við fatlaða og má ætla að hinn mikli fjöldi sveitarfélaga í svo fámennu landi geti aukið flækjustigið í rekstri málaflokksins. Sú staðreynd kallar enn frekará að vel sé staðið аð yfirfærslu sem pessari, en pað var einmitt eitt af pví sem var skoðað í pessari rannsókn. Rannsóknarspurningar voru prjár: A) Var yfirfærsla á málaflokki fatlaðs fólks frá ríki til sveitarfélaga nægjanlega vel undirbúin að mati lykilstarfsmanna í málaflokknum? B) Hvaða áhrif hefur yfirfærslan haft á pjónustupega að mati sömu aðila? C) Hvaða áhrif hefur yfirfærslan haft á starfsfólk að mati sömu aðila?

Tafla 1. pjónustusvæði eftir sveitarfélögum pegar yfirfærslan átti sér stað árið 2011

\begin{tabular}{|c|c|}
\hline $\begin{array}{l}\text { Sveitarfélög sem stóđu ein að } \\
\text { pjónustu við fatlað fólk }\end{array}$ & $\begin{array}{l}\text { Sveitarfélög sem höfđu samstarf } \\
\text { um pjónustu við fatlað fólk }\end{array}$ \\
\hline Kópavogsbær & Mosfellsbær og Kjósarhreppur \\
\hline Vestmannaeyjar & Reykjavíkurborg og Seltjarnarneskaupstaður \\
\hline Sveitarfélagið Hornafjörður & Álftanes og Garđabær \\
\hline \multirow[t]{8}{*}{ Hafnarfjarðarkaupstaður } & pjónustusvæđi Suđurlands: 13 sveitarfélög \\
\hline & pjónustusvæđi Suðurnesja: 5 sveitarfélög \\
\hline & pjónustusvæđi Vesturlands: 10 sveitarfélög \\
\hline & Pjónustusvæđi Norđurlands vestra: 10 sveitarfélög \\
\hline & pjónustusvæði Austurlands: 8 sveitarfélög \\
\hline & Pjónustusvæđi Eyjafjarđar: 5 sveitarfélög \\
\hline & Pjónustusvæði Vestfjarđa: 9 sveitarfélög \\
\hline & Pjónustusvæđi Norđausturlands: 6 sveitarfélög \\
\hline
\end{tabular}

\section{Aðferð}

Í pessum kafla er pví lýst hvernig rannsóknin var framkvæmd, hvernig pátttakendur voru valdir og hvernig haft var samband við pá. Einnig er fjallað um úrvinnslu á gögnum sem féllu til í rannsókninni. Um eigindlega rannsóknaraðferð var að ræða. Eigindlegar og megindlegar rannsóknaraðferðir eiga pað sameiginlegt að par eru skoðaðar bæði kenningar og gögn og samspilið par á milli á skipulagðan hátt. Рað er pó munur á pessum tveimur rannsóknaraðferðum og í stuttu máli má segja að hann liggi í pví að með eigindlegum rannsóknaraðferðum séu skoðuð fá mál í víðu samhengi en með megindlegum rannsóknaraðferðum mörg mál í pröngu samhengi (Ragin 1994).

\subsection{Pátttakendur}

Rannsókn pessi var byggð á opnum upplýsingaviðtölum við fagfólk sem hefur unnið við yfirfærsluna á málaflokki fatlaðs fólks með einum eða öðrum hætti. Annaðhvort vann pað í skipulagningu og stjórnun eða beinni vinnu með pjónustupegum eftir að yfir- 
færslan átti sér stað. Tekin voru viðtöl við átta fagaðila, einn aðila frá velferðarráðuneyti, einn aðila frá Sambandi íslenskra sveitarfélaga og einn fagaðila af hverri pjónustumiðstöð í Reykjavík (alls sex viðtöl). Viðmælendur frá Sambandi íslenskra sveitarfélaga og velferðarráðuneytinu voru valdir vegna stöðu sinnar og pekkingar á efninu en yfirsýn peirra miðast við allt landið. Forstöðumenn pjónustumiðstöðvanna völdu viðmælendur paðan og voru beðnir að velja starfsmenn sem hefðu hvað mesta pekkingu á málaflokknum. Pannig voru viðmælendur annars vegar frá tveimur stofnunum sem sjá um málaflokkinn yfir allt landið og hins vegar frá öllum pjónustumiðstöðvum í Reykjavík, höfuðborg landsins.

Viðmælendur voru af báðum kynjum og höfðu fjölbreytta reynslu og menntun. Viðtöl voru tekin við proskapjálfa, félagsráðgjafa, sálfræðing, starfsmann með B.A.-gráðu í uppeldis-og menntunarfræði og annan með meistaragráðu í fötlunarfræðum svo eitthvað sé nefnt. Menntun viðmælenda og starfsreynsla var æði víðtæk en allir höfðu peir komið að vinnu með fötluðu fólki með einhverjum hætti, mismikið pó. Sumir höfðu verið í beinni vinnu með fötluðu fólki hjá ríki og borg í rúmlega 20 ár, á meðan aðrir höfðu fremur tengst vinnunni sem stjórnendur hjá sveitarfélagi. Dæmi um fyrri störf viðmælenda sem tengdust málaflokknum voru: starf á Kópavogshæli, forstöðumaður sambýlis og bæjarstjóri. Aldur viðmælenda var nokkuð breytilegur og útskriftarár peirra spönnuðu tímabilið 1963 til 2006.

\subsection{Framkvæmd}

Í pessari rannsókn voru tekin eigindleg viðtöl með pað að markmiði að fá innsýn í undirbúning og framgang yfirfærslu málefna fatlaðs fólks út frá pekkingu og reynslu peirra sem vinna í málaflokknum frá degi til dags. Ákveðið var að afmarka viðmælendur hjá sveitarfélögum við stærsta sveitarfélag landsins, Reykjavíkurborg. Útbúinn var viðtalsvísir og upplýst sampykki. Dæmi um spurningar í viðtalsvísinum voru eftirfarandi: Hvernig er pverfaglegu samstarfi háttað? Kom starfsfólk til vinnu frá ríki inn á pjónustumiðstöðina? Hvernig gekk sú aðlögun? Við gerð upplýsts sampykkis voru viðmið frá Landlæknisembættinu höfð til hliðsjónar. Kynningarbréf var samið og sent til forstöðumanna allra pjónustumiðstöðvanna. Peir bentu síðan á einstakling sem peir töldu henta best til að svara spurningum um yfirfærsluna. Var pá haft samband við viðkomandi í gegnum tölvupóst og beðið um leyfi til viðtals. Kynningarbréfið fylgdi með. Allir sex sem haft var samband við voru tilbúnir til pess að fara í viðtal og fóru viðtölin fram á pjónustumiðstöð viðkomandi. Beðið var um leyfi til að hljóðrita samtalið og svo hófst viðtalið. Viðtölin voru mislöng en flest í kringum 30 mínútur. ๖að stysta var 18 mínútur en pað lengsta 38 mínútur. Viðmælendur hjá Sambandi íslenskra sveitarfélaga og hjá velferðarráðuneytinu fengu tölvupóst par sem óskað var eftir viðtali við pá. Viðtölin fóru fram á skrifstofum peirra. Einnig fengust leyfi til að nafngreina pessa tvo viðmælendur vegna eðlis starfa peirra.

Allir viðmælendur voru beðnir að lesa yfir og skrifa undir upplýst sampykki par sem fram komu upplýsingar um markmið og tilgang rannsóknarinnar og peim var gerð grein fyrir pví að peir mættu sleppa pví að svara einstökum spurningum. Pess ber að geta að 
peir sem starfa á pjónustumiðstöðvunum höfðu fengið póst frá yfirmanni sínum par sem bent var á pá og rannsóknin kynnt. Möguleiki er pví á að einhverjir hafi fundið sig knúna til pess að taka pátt par sem bréf barst frá yfirmanni um rannsóknina. Vonandi hefur petta pó haft engin eða lítil áhrif á svör viðmælenda. Til pess að reyna að tryggja heiðarleika og einlægni af hálfu viðmælenda eru viðmælendur af pjónustumiðstöðvunum ekki nafngreindir. Viðmælendur frá Sambandi íslenskra sveitarfélaga og velferðarráðuneytinu koma hins vegar fram undir nafni par sem líklegt er að efni úr viðtölum við pá hefði verið persónurekjanlegt, prátt fyrir nafnleynd, vegna eðlis starfa peirra. Viðtölin fóru fram á vinnutíma haustið 2012.

\subsection{Skráning og úrvinnsla gagna}

Eftir að öll viðtölin höfðu verið tekin voru gögn afrituð. Hvert viðtal fyrir sig var skrifað upp og pau greind með eigindlegri aðferðafræði. Helstu pemu voru dregin fram í niðurstöðum rannsóknarinnar (Rubin \& Babbie, 2005).

\subsection{Siðferðileg álitamál}

Rannsókn pessi var tilkynnt til Persónuverndar (e.d.) og var nr. S5959/2012 en ekki pótti ástæða til að sækja um leyfi Persónuverndar eða Vísindasiðanefndar par sem ekki átti að skoða viðkvæmar persónuupplýsingar (Persónuvernd e.d.). Reglur Reykjavíkurborgar gera ráo fyrir að allar rannsóknir sem framkvæmdar eru innan borgarinnar hljóti sampykki Mannauðsskrifstofu borgarinnar. Sótt var um slíkt leyfi og fékkst pað án athugasemda. Leyfið var sent til forstöðumanna allra pjónustumiðstöðvanna.

\section{Niðurstöður}

Eftir að viðtölin höfðu verið afrituð hófst pemagreining. Helstu pemu sem komu fram í viðtölunum voru: undirbúningur, fjármagn, pverfagleg vinna, starfsmenn, væntingar notenda og samningur Sameinuðu pjóðanna um málefni fatlaðs fólks.

\subsection{Undirbúningur yfirfærslunnar}

Einar Njálsson hjá velferðarráðuneytinu taldi að ýmislegt hefði mátt betur fara við undirbúning yfirfærslunnar. Hann komst svo að orði:

Gagnvart starfsmönnum og notendum pá hefði til dæmis lagasetning purft að liggja fyrir að minnsta kosti sex mánuðum fyrr en raunin var. Lögin um yfirfærsluna voru sampykkt 17. desember 2010 og yfirfærslan átti sér stað með formlegum hætti 1. janúar 2011, sem sagt tæpum hálfum mánuði seinna. Рað var allt of skammur tími.

Hann taldi prátt fyrir petta að yfirfærslan hefði gengið vel, par sem hann vissi ekki til pess að neinar kvartanir hefðu borist velferðarráðuneytinu í kjölfar hennar pegar rannsóknin fór fram. En par kveður við nokkuð annan tón en hjá öðrum viðmælendum. Fram kom hjá viðmælendum frá pjónustumiðstöðvunum að undirbúningstíminn hefði verið mjög 
knappur og pað hefði purft að huga að ýmsum páttum við undirbúning yfirfærslunnar. Einn viðmælandi talaði um hvernig sú undirbúningsvinna hefði bæst ofan á starfið hans og sagði í raun vissa undirbúningsvinnu enn vera í gangi tæplega tveimur árum eftir yfirfærslu, par sem ekki hefði tekist að leysa tiltekin viðfangsefni:

... og pað hefði purft að gera svo margt svo miklu betur, tölvukerfið okkar til dæmis „matchar“ ekki saman og pað er ennpá vinna í gangi og pví er ekki nærri pví lokið, sko, bara að allar skráningar og yfirsýn sé í lagi.

Annar viðmælandi hjá pjónustumiðstöð komst svo að orði:

Eins og gerist á Íslandi, allt svolítið á síðustu stundu, auðvitað hefur eitthvað verið undirbúið upp á skrifstofu velferðarsviðs en ég get ekki séð að pað hafi komið mikið til okkar, sá undirbúningur.

Gyða Hjartardóttir hjá Sambandi íslenskra sveitarfélaga taldi margt hafa verið undirbúið vel en að pað hefði mátt undirbúa ákveðna pætti betur og pá ekki síst að klára lagasetningu fyrr:

... lögin voru ekki tilbúin fyrr en í desember, pannig að mér finnst að undirbúningurinn hefði mátt vera betri, til dæmis bara í lagalegu tilliti. Reglugerðirnar voru að koma seint, pannig að sveitarfélögin náðu ekkert að undirbúa sig af einhverju viti fyrr en pau voru komin með málaflokkinn í fangið.

Ljóst er að fyrirvarinn var of skammur fyrir sveitarfélögin, par sem endanleg ákvörðun um yfirfærsluna með lagasetningu fór ekki fram fyrr en um tveimur vikum áður en hún átti sér stað.

\subsection{Fjármagn}

Enginn sem hefur einhvern tíma séð sjónvarpsfréttir eða opnað dagblað hefur sennilega komist hjá pví að rekast á umræðu um niðurskurð, fjárveitingar og að pað vanti fjármagn í einhverja pjónustu. Pví er kannski ekki skrítið að eitt pemað sem kom fram sneri einmitt að fjármagni. Viðmælendur töldu nokkuð prengt að fjármögnun er varðar suma starfsemi innan málaflokksins. Sumir viðmælendur pjónustumiðstöðvanna höfðu orð á pví að málaflokkurinn hefði verið fjársveltur lengi. Einn viðmælandinn orðaði pað svo:

En raunveruleikinn er bara ekki pannig, pví pað eru bara ekki til neinir peningar, pað fylgdi náttúrulega ekki nægur peningur. Đað er náttúrulega búið að svelta pennan málaflokk í mörg ár, áður en hann kemur yfir til sveitarfélaganna, hann kemur fjársveltur til sveitarfélaganna og 
pað er bara að sýna sig eftir pví sem við erum að kynnast honum betur og betur að pað er svo vanreiknað að pað er náttúrulega út í hróa hött.

Annar viðmælandi lýsti svipuðu sjónarmiði:

Sko, pessi málaflokkur hefur náttúrulega verið sveltur í mörg mörg mörg herrans ár og ég held að pað hafi tekið Reykjavíkurborg svona um pað bil ár, eða kannski minna, að átta sig á pví að pessum málaflokki fylgdu bara engan veginn nægjanlegir peningar.

Auk pess kom fram hjá viðmælendum frá pjónustumiðstöðvum að pað fylgdu langir biðlistar á sumum svæðum, sem sýndi að ekki hefði fylgt nægilegt fjármagn með málaflokknum.

Gyða Hjartardóttir hjá Sambandi íslenskra sveitarfélaga benti á að pað fælist ákveðin hagræðing í pví að færa málaflokkinn yfir til sveitarfélaga og að hægt yrði að nota hugsanlegan fjárhagslegan ávinning til að bæta pjónustu við fatlaða, meðal annars með pví að próa úrræði í húsnæðismálum:

... að samlegðaráhrifin yrðu pannig að við erum að veita sömu pjónustu fyrir aðeins minni pening og pá er hægt að velta meiri pening 1 pjónustu sem og húsnæðisúrræði sem hefur verið skortur á.

Einar Njálsson hjá velferðarráðuneytinu kom jafnframt inn á styrkingu útsvars og pá tekjuaukningu sem pví fylgdi:

Útsvarsstofninn var veikur á miðju ári 2010 pegar samið var um hinn fjárhagslega ramma. Síðan pá hefur útsvarsstofninn verið að styrkjast verulega. Jafnvel svo að pessi 1,2 prósentustig hafa gefið sveitarfélögunum umtalsverðar tekjur og að einhverju marki betri tekjur en sem svarar launabreytingum sem orðið hafa á tímabilinu. Útsvarsstofninn á að vega inn launabreytingar, pannig að sveitarfélög fái tekjuaukningu á móti kauphækkunum samkvæmt kjarasamningum. Útsvarsstofninn virðist hafa verið að gefa heldur rýmri tekjur. Miðað við pað að ekki dragi úr pessari próun, pá er óvíst að pörf verði á pví að hækka útsvarsprósentuna.

Gyða Hjartardóttir hjá Sambandi íslenskra sveitarfélaga hafði greinilega komist að svipaðri niðurstöðu: „Útsvarið hefur verið aðeins á uppleið, pannig að pað hefur komið meira inn í málaflokkinn en við bjuggumst við.“ Hins vegar taldi Gyða, eins og Einar, að megnið af peim aukatekjum sem hefðu borist hefði farið í hærri launakostnað.

Dannig má sjá að of lítið fjármagn virðist hafa fylgt pessum málaflokki af hálfu hins opinbera lengi. Launakostnaður er stór hluti kostnaðar í pjónustu sem pessari og 
kjarasamningar sem fela í sér hærri launakostnað geta pví gert málaflokknum erfitt fyrir, nema aukið fjármagn frá hinu opinbera fylgi um leið.

\section{3 pverfaglegt samstarf}

Í vinnu með fötluðu fólki parf að huga að mörgu pegar aðstoð er veitt. Eins og áður hefur komið fram snertir pjónusta við fatlað fólk öll svið daglegs lífs og pví parf að hafa ákveðna heildarsýn við pessa vinnu. Fagfólk á pessu sviði parf pví oft á tíðum að vinna með öðru fagfólki að úrlausn mála. Eitt pemað sem kom fram í gögnunum var pverfagleg vinna og virtist vera mikið um pverfaglega vinnu í málaflokknum á pjónustumiðstöðvunum. Sú vinna virtist yfirleitt ganga vel. Einn viðmælandi frá pjónustumiðstöð sagði svo einnig hafa verið fyrir yfirfærsluna: „Já, mjög mikil, pað er mjög mikil pverfagleg vinna hjá Reykjavíkurborg og reyndar mjög mikil pverfagleg vinna í pjónustu við fatlað fólk fyrir yfirfærslu. “ Gyða Hjartardóttir sagði einnig að pverfagleg vinna væri í gangi hjá Sambandi íslenskra sveitarfélaga: „Hér er náttúrulega bara unnið pverfaglega, pað er einn félagsráðgjafi starfandi hérna, svo eru hagfræðingar, viðskiptafræðingar, lögfræðingar, kennarar, stjórnsýslufræðingur og fleiri starfsstéttir.“

Eins og Gyða bendir á getur slík samvinna gengið vel en dæmi eru um að hún gangi illa:

Раð er enginn að spá í einhverja múra hérna, svona faglega múra. Баð eru bara allir jafnir og vinna allir mjög vel saman og bara nýtt sérfræðipekkingin hvers og eins. Pessir faglegu múrar eru ekki hér innan húss en ég pekki pað náttúrulega annars staðar frá, úr öðrum störfum.

Pannig virðist vera mikið um pverfaglegt samstarf í málaflokknum og að öllu jöfnu virðist pað ganga vel.

\subsection{Sértæk pekkingarmiðstöð um málefni fatlaðs fólks}

pjónustumiðstöðvarnar í Reykjavík eru sex talsins, eins og áður hefur komið fram, og var ein peirra, Djónustumiðstöð Laugardals og Háaleitis, skráð sem pekkingarmiðstöð í málefnum fatlaðs fólks. Athyglisvert var að skoða hvernig pví starfi væri háttað, hvort pjónustumiðstöðin héldi úti fræðslu eða gæfi sig út fyrir að aðrir gætu leitað pangað með spurningar sem kynnu að vakna. Eitthvað virtist misjafnt hvort og hversu mikið aðrar pjónustumiðstöðvar nýttu sér pessa sértæku pekkingarmiðstöð. Viðmælendur virtust pannig lítið leita sér aðstoðar eða afla sér pekkingar frá pessari pjónustumiðstöð. Einn viðmælandi taldi ekki pörf á að leita eftir upplýsingum par, pví pau væru vel sett að pví leyti, en virtist einnig hafa takmarkaðar væntingar til pessarar stöðvar: „Nei, við erum með rosa góða pekkingu á málefnum fatlaðra, pannig að pessi stöð er vel sett með pekkingu. Ég held svolítið að petta sé ekki alveg að „funkera“ í raun, skilurðu, ég held að petta hafi eitthvað dalað.“ Annar viðmælandi taldi pó góða pekkingu vera til staðar á málaflokknum hjá pessari tilteknu pjónustumiðstöð: „Ég held að pau séu mjög sterk í málaflokki fatlaðra innan pjónustumiðstöðvarinnar, með marga aðila sem að 
vinna í málaflokknum, sem að sérhæfa sig í málaflokknum, ég veit bara að við leitum ekki til peirra."

En dæmi voru einnig um hik við að leita sér aðstoðar eða pekkingar frá pessari pjónustumiðstöð og að viðmælandi teldi starfsfólk ekki vita almennilega hvernig pað ætti að bera sig að:

Ég hugsa að flestir félagsráðgjafar hérna myndu ekkert vita hvern peir ættu að hringja í, pað er bara af pví að ég er í málaflokknum að ég veit hvern ég á að hringja í. Рað er ekki pannig að pau segi ef pið leitið til okkar, pá getið pið hringt í pennan út af pessu, pað er ekki pannig.

Enn annar viðmælandi taldi pessa pjónustumiðstöð ekki miðla pekkingu sinni nægilega vel til annarra pjónustumiðstöðva: „Đau gefa sig ekki út fyrir að vera að miðla sinni pekkingu annað, eflaust fengi maður svör ef maður leitaði en einhvern veginn dettur manni ekki í hug að gera pað.““

Starfsmaðurinn hjá pekkingarpjónustumiðstöðinni kom með skýringu á pví af hverju svo lítið væri um miðlun pekkingar til annarra pjónustumiðstöðva: „Fyrir yfirfærslu pá vorum við með fræðslu, við bara höfum ekki mannafla til pess núna, en pjónustumiðstöðvarnar leita heilmikið til okkar.“ Athyglisvert er að starfsmaður pekkingarpjónustumiðstöðvarinnar taldi að mun fleiri leituðu til peirra en fram kemur hjá viðmælendum frá öðrum pjónustumiðstöðvum. pessi sami starfsmaður taldi pörf fyrir fræðslu meðal annarra pjónustumiðstöðva auk pess hafa minnkað í kjölfar yfirfærslunnar:

рað er líka minni pörf á fræðslu á milli heldur en var pví pað er náttúrulega fleira fólk í pessum málaflokki og allar pjónustumiðstöðvar fengu til dæmis búsetukjarna yfir til sín og par ertu með forstöðumann sem er yfirleitt fagaðili og svo er pað náttúrulega bara reynslan.

Af pessum svörum viðmælenda að dæma virðist fara tvennum sögum af pví hversu mikið hafi verið leitað til Pjónustumiðstöðvar Laugardals og Háaleitis eftir fræðslu er varðar málefni fatlaðs fólks. Fulltrúar pjónustumiðstöðvanna töldu aðrar pjónustumiðstöðvar ekki leita mikið til pekkingarpjónustumiðstöðvarinnar en fulltrúi pekkingarpjónustumiðstöðvarinnar taldi aðrar pjónustumiðstöðvar leita mikið til hennar. Ekki virðist pekkingarpjónustumiðstöðin hafa haft mannafla til pess að fara með fræðsluna út á mörkina í kjölfar yfirfærslunnar. Hins vegar töldu sumir viðmælendur að mikil pekking væri innan pekkingarpjónustumiðstöðvar á málefninu.

\subsection{Starfsfólk}

Fram kom hjá Einari Njálssyni hjá velferðarráðuneytinu að 1.500 starfsmenn hefðu færst frá ríki til sveitarfélaga við yfirfærsluna. Vissulega er fjarri pví að allir pessir starfsmenn hafi farið að vinna hjá Reykjavíkurborg, en um töluverðan fjölda hefur pó verið 


\section{STJÓRNMÁL \& \\ STJÓRNSÝSLA}

að ræða par sem Reykjavík er stærsta sveitarfélagið hér á landi. Starfsmenn pessir höfðu annars vegar unnið á svæðisskrifstofu við pau störf sem fluttust til félagspjónustu við yfirfærsluna og hins vegar við hin ýmsu úrræði sem standa fötluðu fólki til boða. Svo virðist sem starfsfólk hafi ekki verið nægilega vel undirbúið fyrir breytingarnar samkvæmt Gyðu Hjartardóttur hjá Sambandi íslenskra sveitarfélaga: „Ég held að pað hafi verið svolítið vanmat, að pað hefði purft að vinna svolítið meira með starfsfólk, maður heyrir pað alla vega að starfsfólki fannst pað ekki nógu vel upplýst.“

Fyrir pað starfsfólk sem vann við hin ýmsu úrræði, eins og til dæmis hæfingarstöðvar og skammtímavistanir, urðu breytingarnar pó takmarkaðar eins og einn viðmælandinn benti á: „Fyrir eins og starfsfólk heimila og pess háttar, nei, petta hefur ekki breytt neinu fyrir pau, bara annar atvinnurekandi, svipuð kjör og réttindi.“ Aftur á móti urðu breytingarnar mun meiri meðal peirra sem fluttu frá svæðisskrifstofu yfir á félagspjónustu. Fram kom hjá viðmælendum að tiltekin menning hefði verið til staðar hjá svæðisskrifstofum sem ekki hefði tekist að undirbyggja nægilega vel í öllum pjónustumiðstöðvunum við yfirfærsluna, eins og eftirfarandi tilvitnun sýnir: „Ég held að starfsfólkið hafi að sumu leyti, starfsfólkið á skrifstofunni, misst svolítið „,back up“ og ákveðinn „culture“ pannig að petta hafi verið erfitt fyrir pau.“

Einnig virtist vera misjafnt hvort hefði komið aðili frá svæðisskrifstofu yfir á pjónustumiðstöðvarnar, eins og kemur fram hjá pessum viðmælanda sem hafði reynslu af pví að starfa á tveimur pjónustumiðstöðvum eftir yfirfærsluna: „Nei, hingað kom enginn við flutninginn, pað stóð til en málið gekk ekki upp og pað endaði pannig að í raun kom enginn hingað við yfirfærsluna.“ Annar viðmælandi taldi að pað аð fá einn starfsmann inn hefði verið of lítið: „Í pessa beinu ráðgjöf og sérfræðipjónustu fengum við bara petta eina stöðugildi.“ Sá viðmælandi taldi að pað hefði purft mun fleira fólk, fleiri en fimm stöðugildi, par sem pessi málaflokkur væri svo gríðarlega undirmannaður.

Af svörum viðmælenda að dæma virðist skortur á fjármagni í málaflokknum að hluta til hafa birst í vanmönnun sem væntanlega hefur haft áhrif á pjónustu við fatlaða. Fram kemur hjá viðmælendum að starfsfólk hafi ekki verið nægilega vel upplýst um yfirfærsluna. Athyglisvert er að yfirfærslan virtist hafa breytt litlu fyrir pá starfsmenn sem unnu í tilteknum úrræðum í málaflokknum. Hins vegar virtist hún gjörbreyta starfsaðstæðum peirra sem störfuðu áður á svæðisskrifstofum um málefni fatlaðra, par sem peir færðust yfir til félagspjónustu.

\subsection{Upplifun viðmælenda af pjónustu við fatlaða og væntingum peirra til breyt- inga við yfirfærsluna}

Hér að framan hefur verið fjallað um helstu atriði er varða starfsfólk og pætti sem snúa að yfirfærslunni. En pjónustupegar skipta pó kannski mestu máli í pessu samhengi og var pví athyglisvert að skoða hvað viðmælendur höfðu að segja um pað hvernig peir teldu að yfirfærslan hefði komið út fyrir fatlað fólk og hverjir kostir og gallar yfirfærslunnar hefðu verið fyrir pjónustupega. Tilteknir kostir virðast vera ótvíræðir, eins og kom fram hjá pessum viðmælanda: „Kostirnir eru að nú parf fólk bara að koma á einn stað, pað kemur bara hingað og sækir um pjónustu.“ Og annar viðmælandi hafði svipaða sögu að 
segja: „,[jónustupegar] purfa pá bara að koma hingað og eru pá bara með einn ráðgjafa í sínum málum.“

par sem ekki er lengur um tvær stofnanir að ræða, pað er svæðisskrifstofu og félagspjónustu, er pjónustan komin á eina hönd og pað dregur úr pví að mál falli á milli, eins og einn viðmælandinn kom inn á:

Dað var hópur fyrir yfirfærslu sem var bara á gráa svæðinu og velferðarsvið vísaði á svæðisskrifstofu og svæðisskrifstofa á velferðarsvið, pannig pað var ákveðinn hópur sem var voða litla pjónustu að fá en náttúrulega dettur inn við pessa sameiningu og pað er pað sem er gott við yfirfærsluna. Ég held að pað fari algjörlega eftir hópnum, petta fólk sem ég var að vísa til að hefði verið á gráa svæðinu, sá hópur fær klárlega betri pjónustu í dag.

Áður virtust tvær stofnanir geta vísað fötluðu fólki sem var á gráu svæði er varðar rétt til pjónustu hvor á aðra, en sá möguleiki er ekki lengur til staðar eftir yfirfærsluna. Tilgangslaust er fyrir sveitarfélag að benda á sjálft sig. Đó virðast fatlaðir ekki fá alla pá pjónustu sem peir eiga rétt á samkvæmt einum viðmælanda: „Samfélagið hefur ekki verið að veita pá pjónustu, hvorki fyrir né eftir yfirfærslu, sem gerir ráð fyrir pví að allir fatlaðir hafi einhvern veginn sama rétt eða sömu getu til samfélagspátttöku og við hin.“

Рað virðist pví vera umtalsvert svigrúm til að bæta pjónustu við fatlað fólk. Detta á sérstaklega við um biðlista, en viðmælendum var tíðrætt um hve slæmt væri að vera með langa biðlista. Ljóst er að ef fólk er lengi á biðlista án pjónustu sem pað parf á að halda er verið að brjóta á rétti pess. Viðmælandi hjá pjónustumiðstöð hafði petta um biðlista að segja: „,एú veist, fólk fór bara á bið, fólk er látið á bið og par með er ekki hægt að segja að við séum ekki að veita lögbundna pjónustu, umsóknin er sampykkt.“

Biðlistar virðast verða til vegna pess að ekki fæst fólk til að sinna viðkomandi störfum eða hreinlega vegna pess að fjármagn vantar til að veita pjónustuna samkvæmt pessum viðmælanda:

Segjum að pú sért að sækja um liðveislu og átt rétt á pví og færð pað. Já, já, pað er allt saman sampykkt en pað fer á bið af pví að við höfum ekki fólk í pað, og í sumum flokkum er ekki til fjármagn, pannig að við megum ekki ráða fólk, pannig pú færð aldrei neitun, pú ferð bara á bið og pá getur pú ekkert kært petta, pannig virkar kerfið, sko.

Dessu virðist hafa verið svipað farið fyrir yfirfærsluna samkvæmt einum viðmælanda: „एað sem við erum að sjá á gögnum frá Svæðisskrifstofunni er að pað var bara raunin, fólk var bara á bið í mörg ár og fékk ekki neitt.“ Annað dæmi um pjónustu sem bið var eftir er búsetuúrræði. Einn viðmælandi lýsti stöðu mála varðandi pað úrræði á eftirfarandi hátt:

pað er líka fullt af fólki sem að býr á herbergjasambýli og vill komast í 


\section{STJÓRNMÁL \& \\ STJÓRNSÝSLA}

sjálfstæða búsetu, pað er á milli flutningsbiðlista, kannski engum akút biðlista en samt biðlista. Er boðlegt að bjóða fólki yfir 50 [ára] að búa enn með öðrum sem að pað vill ekki búa með og er fast á biðlista eftir pví að komast í íbúð með pjónustu?

Pannig má sjá að pað að vera á biðlista eftir mikilvægri pjónustu getur verið verulega ípyngjandi fyrir fólk. Annar viðmælandi tók dæmi um bið eftir búsetuúrræði og áhrif hennar á líf aðstandenda:

Раð parf svolítið að opna augu fólks fyrir pví hvað petta er alvarlegt, ég meina ég er með foreldra á pessum biðlista par sem annað foreldrið getur ekki unnið lengur. Ég meina, pau eiga ekki barn, pau eiga fullorðinn mann sem pau purfa samt að sinna 24/7 og ég meina, pau eru ekkert eina dæmið en pað er alveg hægt að taka ákvörðun um að koma pessum málum í lag, en pað kostar peninga.

Pegar Einar Njálsson hjá velferðarráðuneyti var spurður út í búsetumál fatlaðs fólks sagði hann eftirfarandi: „Ég skal ekki segja hvort að ríkið muni styðja við einhvers konar lánafyrirgreiðslu í gegnum opinbera sjóði, kannski Íbúðalánasjóð eða eitthvað slíkt, til pess að auðvelda sveitarfélögum að fjármagna stofnkostnað. Hugmyndir af pví tagi hafa verið viðraðar.“

En pað var ekki nóg með að biðtími gæti verið langur og jafnvel til málamynda eftir tiltekinni pjónustu. Раð virtist einnig vera um misgóða pjónustu að ræða meðal pjónustumiðstöðva, eins og einn viðmælandi nefndi: „Ég held að pað skipti stóru máli hvort pú sért fatlaður hér eða í [X], pað skiptir heilmiklu máli upp á pjónustu pó að regluverkið sé hið sama.“ Fleiri viðmælendur töldu að munur væri á gæðum pjónustunnar. Einn sagði stutt og laggott: „Раð er munur á öllum stöðvunum.“ Annar var svipaðrar skoðunar: „Đví miður pá held ég að pað skipti verulegu máli á hvaða pjónustumiðstöð pú leitar með hvaða ráðgjöf og hvaða pjónustu pú færð.“

Pannig töldu nokkrir viðmælendur pjónustumiðstöðva að pjónustupegum væri mismunað eftir pjónustumiðstöðvum. Auk pess virtust vera dæmi um að pjónustunni hefði hrakað á einhvern hátt í kjölfar yfirfærslunnar. Til dæmis nefndi einn viðmælandi að pjónustupegar hefðu verið minntir á pað af viðkomandi svæðisskrifstofu að umsóknarfrestur vegna tiltekinnar pjónustu væri að renna út og að tími væri kominn til að endurnýja pjónustuna. Eftir yfirfærsluna hefði pað hins vegar verið alfarið á ábyrgð notandans að fylgjast með pessum málum. Баð má velta pví fyrir sér hvort ekki hefði verið einfalt að koma upp áminningarkerfí í gegnum netföng notenda eins og tíðkast til dæmis varðandi bókasafnsskil. Fleiri atriði voru nefnd sem hefðu verið í betra horfi fyrir yfirfærslu, eins og einn viðmælandi bendir á: „En hins vegar held ég að pað hafi skipt marga pjónustupega hér máli af pví að pjónustan á svæðisskrifstofunni hafi verið mun persónulegri og passað betur upp á notendurna, meira utanumhald.“

Einnig kom fram meðal viðmælenda að svo virtist sem pjónustupegar hefðu haft 
ákveðnar væntingar um að pjónustan yrði betri en hefðu svo orðið fyrir vissum vonbrigðum með að svo skyldi ekki verða, eins og einn viðmælandi nefndi: „Ég held að petta hafi verið mjög mikil vonbrigði fyrir mjög marga." Annar viðmælandi hafði svipaða sögu að segja: „Við heyrðum pað mjög mikið að fólki fannst voða lítið hafa gerst við pessa yfirfærslu.“ Væntingarnar virtust hafa verið byggðar á pólitískum loforðum samkvæmt einum viðmælandanum: „En pað voru rosaleg loforð í aðdraganda yfirfærslunnar, allt átti að verða miklu betra og miklu betri pjónusta og pólitíkin alveg bara, hvað petta átti allt að verða frábært, pannig að fyrir fólk var petta vonbrigði.“

pannig virtist yfirfærslan hafa haft pau jákvæðu áhrif að öll pjónusta varð á einni hendi og pví gátu stofnanir ekki lengur vísað hver á aðra ef fatlað fólk var á gráu svæði varðandi rétt á pjónustu. Hins vegar virðist pjónustunni að einhverju leyti hafa hrakað í kjölfar yfirfærslunnar, par sem ekki virðist vera haldið jafn pétt utan um pjónustupega og áður. Auk pess töldu nokkrir viðmælendur pjónustumiðstöðva að pjónustan væri misjöfn að gæðum eftir miðstöðvum.

\subsection{Samningur Sameinuðu pjóđanna um málefni fatlaðs fólks}

Viðmælendur voru spurðir um fullgildingu Samnings Sameinuðu pjóðanna (2006) um málefni fatlaðs fólks en undirbúningsvinna fyrir innleiðingu samningsins fór fram í innanríkisráðuneytinu og velferðarráðuneytinu pegar rannsókn pessi var gerð. Pví var áhugavert að vita hvort viðmælendur teldu að pað myndi breyta einhverju fyrir fatlað fólk á Íslandi að fullgilda samninginn. Einkum var petta forvitnilegt par sem ljóst er að í einhverjum tilfellum er fötluðu fólki ekki veitt fullnægjandi pjónusta. Einn viðmælandi taldi að langt væri frá pví að hér væri veitt pjónusta á við pað sem samningurinn kvæði á um: „Við höfum bara ekki pað „,capacitet“ eða fjármagn sem parf til að geta gert petta eins og til dæmis Samningur sameinuðu pjóðanna segir til um og bara virkilega er réttindi fólks.“ Annar viðmælandi taldi fullgildingu samningsins geta breytt réttarstöðu fatlaðs fólks:

Gæti auðveldlega gert pað út af pví að pá, allt í einu, er kominn fastur punktur varðandi lög, og pað er pá hægt að kæra hluti sem að - eða pjónustu eða skort á pjónustu sem að ekki hefur verið hægt áður.

Annar viðmælandi benti á betri réttarstöðu fatlaðs fólks við fullgildingu samningsins: „En ef petta er einhvern veginn komið í lög pá, að pú verðir að mæta fólki svona, pá getur fólk jafnvel farið að fara með, fara í mál og svoleiðis ef pað er ekki verið að gera pað sem pað á rétt á.“ Einn viðmælandi taldi fullgildingu samningsins pó ekki mundu breyta miklu: „Sko, tilfinningin er sú að pað muni í rauninni ekki breyta, pó að ég fagni pví auðvitað, en ég er ekki viss um að pað muni breyta miklu, en ég vona pað.“

Pannig virtust viðmælendur ekki vera á sama máli um mikilvægi Samnings sameinuðu pjóðanna um réttindi fatlaðs fólks. Sumir töldu að samningurinn myndi ekki breyta miklu á meðan aðrir töldu að samningurinn myndi tryggja réttindi fatlaðs fólks til pjónustu mun betur. 


\section{STJÓRNMÁL \& \\ STJÓRNSÝSLA}

\section{Umræða}

Margt athyglisvert kom fram í viðtölunum við viðmælendur í pessari rannsókn. Viðmælendur töldu að til lengri tíma litið yrði yfirfærslan jákvæð fyrir pjónustupega, par sem pjónustan yrði á einni hendi, en lítið hefði bó breyst meðal fatlaðs fólks svo skömmu eftir yfirfærsluna. Meira fjármagn pyrfti í málaflokkinn og æskilegt hefði verið að lögin hefðu verið tilbúin að minnsta kosti sex mánuðum fyrr.

Reykjavík er stærsta sveitarfélag landsins og var pví ákveðið að taka pað fyrir sérstaklega í rannsókninni. Innan Reykjavíkurborgar eru bæði pjónustumiðstöðvar og velferðarsvið og eftir á að hyggja hefði verið áhugavert að taka einnig viðtal við aðila á velferðarsviði borgarinnar. Helstu veikleikar pessarar rannsóknar má pví segja að hafi verið að taka ekki viðtöl við aðila á velferðarsviði borgarinnar. Auk pess hefðu viðtöl við aðila sem skipuleggja daglega pjónustu við pjónustupega mögulega gefið raunsannari upplýsingar. Jafnframt hefði rannsóknin verið yfirgripsmeiri og gefið meiri upplýsingar um heildarmyndina á landsvísu ef tekin hefðu verið viðtöl við lykilaðila í málaflokknum á landsbyggðinni. Hefði pá ekki síst verið athyglisvert að skoða annars vegar pjónustu út frá stærð pjónustusvæða og hins vegar út frá pví hvort eitt sveitarfélag stendur að baki pjónustu eða nokkur.

Styrkleikar rannsóknarinnar eru að sama skapi að samband náðist við lykilaðila á öllum pjónustumiðstöðvum Reykjavíkurborgar sem og hjá velferðarráðuneytinu og Sambandi íslenskra sveitarfélaga, eins og ætlunin var. Viðmælendur voru pannig annars vegar frá tveimur stofnunum sem pjónusta allt landið og hins vegar frá öllum pjónustumiðstöðvum stærsta sveitarfélagsins, Reykjavíkurborgar. Allir viðmælendur voru vel kunnugir bæði málefnum fatlaðs fólks og málum tengdum yfirfærslunni á málaflokknum frá ríki til sveitarfélaga og pví ættu skoðanir peirra að gefa nokkuð raunsæja mynd af pví hvernig hlutirnir gengu fyrir sig og hvað helst pyrfti að bæta.

Hvort yfirfærslan hafi verið nægilega vel undirbúin er erfitt að segja til um. Баð virðist pó ljóst að lagasetning hefði purft að vera tilbúin mun fyrr. Af orðum eins viðmælanda virðist mega marka að ríkið muni draga lærdóm af pví og verður forvitnilegt að fylgjast með hvort sú verði raunin í öðrum yfirfærslum sem ríkið kann að ráðast í, til dæmis á málaflokki aldraðra.

Sé litið til æskilegs breytingaferlis Kotter (1996) í átta liðum, sem lýst var hér að framan, virðist breytingaferlið einungis hafa samræmst tveimur liðum pess að einhverju leyti. Undirbúningur hafði staðið yfir í nokkurn tíma, par sem lengi höfðu verið ræddar hugmyndir um yfirfærsluna (A-liður). Ljóst var að áframhaldandi breytingar pyrftu að verða, en ekki hafði verið lokið við yfirfærsluna að fullu pegar rannsóknin fór fram og var enn verið að vinna að frekari breytingum. Má par nefna að enn var eftir að laga tölvukerfið að breytingunum hjá Reykjavíkurborg (G-liður). Svo virðist sem liðum B til og með E í breytingaferli samkvæmt Kotter (1996) hafi verið sleppt, enda vannst ekki tími til að fara í gegnum pá par sem yfirfærslan gekk í gegn einungis tveimur vikum eftir formlega sampykkt hennar á Alpingi. Síðasti liðurinn í breytingaferli Kotter (1998), sem felst í pví að breytingarnar eru endanlega festar í sessi, var ekki afstaðinn pegar rannsóknin var gerð (H-liður). 
Pegar viðtölin öll eru skoðuð nánar út frá kenningu Kotter (1998) um breytingastjórnun má sjá að pað hefði verið algjört lykilatriði í pessum breytingum að stuðla að góðu samstarfsumhverfi milli pekkingarmiðstöðvarinnar annars vegar og annarra pjónustumiðstöðva hins vegar. Pví má velta fyrir sér hvort ekki hefði verið gott að koma á meiri samvinnu til pess að pekkingin einangraðist ekki á einum stað og allir væru að finna upp hjólið í eins eða sambærilegum aðstæðum sem geta komið upp í málaflokknum innan pjónustumiðstöðvanna. Velta má pví fyrir sér hvort pað að ein af pjónustumiðstöðvunum sex var pekkingarmiðstöð hafi gert pað að verkum að starfsfólk átti erfiðara með að leita til hennar, par sem pær voru á jöfnum grunni, en ef sérfræðingar í málaflokknum hefðu verið á velferðarsviði, sem er stjórnunarlega yfir pjónustumiðstöðvunum. Einnig má ætla að grundvallaratriði hafi verið að gott samstarf skapaðist á milli fyrrum starfsmanna svæðisskrifstofu og nýrra samstarfsfélaga á pjónustumiðstöðvum. Баð samstarf hefði purft að undirbúa vel. Рað virtist hafa tekist vel í sumum tilfellum en ekki í öllum. Áhugavert væri að skoða hvernig pað ferli fór fram og hvernig starfsfólkið sem vann áður á svæðisskrifstofum upplifði yfirfærsluna. Athyglisvert er að svo virðist sem meira utanumhald hafi verið pegar málaflokkurinn var hjá svæðisskrifstofum, og pað gæti bent til pess að pær hafi verið smærri rekstrareiningar, en ólíklegt er að svo hafi verið í Reykjavík. Ekki er hægt að segja til um pað út frá niðurstöðum pessarar rannsóknar hvort pjónustan, sem ætti að vera meira í nærsamfélaginu eftir yfirfærslu, hafi skilað sér í valdeflingu fyrir pjónustupega. Раð er nokkuð sem mikilvægt er að rannsaka frekar pegar pjónustan hefur verið á vegum sveitarfélaganna í nokkurn tíma. Đá væri æskilegt að rannsaka með eigindlegum aðferðum upplifun notenda af pjónustunni fyrir og eftir yfirfærslu málaflokksins.

Fyrir ákveðinn hóp pjónustupega má ætla að yfirfærslan hafi skipt töluverðu máli. раð er hópur sem einn viðmælandi benti á að hefði fallið pað illa undir skilgreiningar að ekki var ljóst á hvers ábyrgð pað væri að sinna honum. Fyrir aðra pjónustupega virtist yfirfærslan ekki hafa breytt miklu pegar rannsóknin var gerð. Viðmælendur töldu að vegna peirra væntinga sem stjórnmálamenn hefðu skapað hefðu pjónustupegar í raun orðið fyrir vonbrigðum eftir að yfirfærslan var afstaðin. Flestir viðmælendur voru pó sammála um að til lengri tíma litið myndi pessi breyting koma notendum til góða, par sem pjónustan yrði á einni hendi og í nærsamfélaginu.

pegar pjónusta við fatlað fólk er skoðuð nánar, pá virðist pað skjóta skökku við að bjóða upp á pjónustu sem svo er í raun ekki veitt svo mánuðum og jafnvel árum skiptir, en sú virðist pó hafa verið staðan í einhverjum tilfellum í málefnum fatlaðs fólks hjá Reykjavíkurborg er varða búsetuúrræði og liðveislu. pjónustan hefur verið í boði en ekki í nægjanlegu magni og sumir pjónustupegar hafa liðið fyrir pað. Biðlistar eftir búsetuúrræðum virðast vera of langir og ekki er alltaf unnt að veita liðveislu vegna skorts á starfsfólki. Biðlistar virðast pví geta verið nokkurs konar skálkaskjól í pessum málaflokki. Hvernig pólitíkin hyggst taka á málefnum fatlaðs fólks er pví lykilatriði. Í pessu samhengi ætti að skoða hvaða pjónustu sem fatlað fólk á rétt á er mikilvægast að veita og finna leiðir til pess að veita hana peim sem hana purfa. Athyglisvert er einnig að niðurstöður pessarar rannsóknar sýna að notendum pjónustunnar virðist vera mismunað eftir búsetu innan Reykjavíkurborgar, samkvæmt viðmælendum, og að gæði pjónustunnar séu pannig mismunandi eftir pví hvar fólk býr innan borgarinnar. 


\section{STJÓRNMÁL \& \\ STJÓRNSÝSLA}

Starfsfólkið skiptist einnig í hópa eftir pví hvaða áhrif yfirfærslan hefur haft á pað. Hjá starfsmönnum í beinni umönnunarpjónustu við fatlað fólk í sértækum úrræðum virðist lítið hafa breyst. Starf peirra starfsmanna á pjónustumiðstöðvum sem koma að vinnu með fötluðum við umsóknir og úrræði virtist hafa breyst og aukist við yfirfærsluna, ekki síst rekstrarhlið starfseminnar. Hópurinn sem var áður hjá svæðisskrifstofum er sennilega sá hópur starfsmanna sem hvað mest hefur fundið fyrir breytingum par sem við tók annar vinnuveitandi og nýtt samstarfsfólk. Фað kemur á óvart að starfsfólk frá svæðisskrifstofu fór ekki inn á allar pjónustumiðstöðvar hjá Reykjavíkurborg.

pessi rannsókn verður vonandi til hagsbóta fyrir málaflokk fatlaðs fólks og veitir frekari innsýn í stöðuna í málefnum fatlaðra hjá Reykjavíkurborg, og að einhverju leyti á landinu öllu. Mikilvægt er að missa ekki sjónar á peim markmiðum sem sett voru í tengslum við yfirfærsluna og vinna parf ötullega að peim áfram. Mikilvægt er að setja ný og framsækin markmið svo að málaflokkur fatlaðs fólks staðni ekki. Alpingi sampykkti viðamikla framkvæmdaáætlun í málefnum fatlaðs fólks par sem tiltekin eru fjölmörg verkefni á átta sviðum. Hefur sú áxtlun nú verið framlengd á meðan unnið er að nýrri framkvæmdaáætlun (Velferðarráðuneytið, a.b.-b). Auk pess var stofnaður starfshópur sem hefur lagt til að unnið verði að nýrri heildarlöggjöf í málefnum fatlaðs fólks og að lögum um félagspjónustu sveitarfélaga verði breytt svo unnt verði að skerpa betur skilin milli pessara tveggja lagabálka (Velferðarráðuneytið, a.b.-c). Dví má segja að málaflokkur pessi sé nú í stöðugri próun.

\section{Heimildir}

Alpingi (e.d.-a). Árni Páll Árnason. Sótt 22. október 2012 af http://www.althingi.is/altext/cv.php4?nfaerslunr $=678$.

Alpingi (e.d.-b). Guðbjartur Hannesson. Sótt 22. október 2012 af http://www.althingi.is/altext/ cv.php4?nfaerslunr $=683$.

Alpingi (e.d.-c). Jóhanna Sigurdardóttir. Sótt 22. október 2012 af http://www.althingi.is/altext/ cv.php4?nfaerslunr=287.

Alpingi (e.d.-d). Páll Pétursson. Sótt 5 október 2012 af http://www.althingi.is/altext/thingm/1703372479.html.

Bäck, H., Gjelstrup, G., Helgesen, M., Johansson, F. og Klausen, J.E. (2005). Urban Political Decentralisation: Six Scandinavian Cities (5. útg.). Wiesbaden: VS verlag für sozialwissenschaften.

Bason, C. (2010). Leading Public Sector Innovation: Co-Creating for a Better Society. Bristol: The Policy Press.

Beresford, P. og Croft, S. (2000). „Empowerment“, Í M. Davies (ritstj.), The Blackwell Encyclopedia of Social Work (bls.116-118). Oxford: Blackwell Publishers.

Christiansen, N.F., Petersen, K., Edling, N. og Haave, P. (2006). The Nordic Model of Welfare: A Historical Reappraisal. Kaupmannahöfn: Museum Tusculum Press.

Gunnar Helgi Kristinsson (2001). Staðbundin stjórnmál, markmið og árangur sveitarfélaga. Reykjavík: Háskólaútgáfan.

Hagfræðistofnun (e.d.). Útgáfa. Sótt 25. nóvember 2012 af http://hhi.hi.is/sites/hhi.hi.is/files/CSeries/2010/C1006_Notendastyrd_personuleg_adstod_og_Kostnardur_vid_thonustu_vid_aldrada_og_fatlada.pdf.

Herold, D. M., og Fedor, D. B. (2008). Leading Change Management - Leadership Strategies that Really Work. London: Kogan Page Limited.

Innanríkisráðuneytið. (e.d.). Málefni fatlaðra. Sótt 5. október 2012 af http://www.jofnunarsjodur.is/malefni-fatladra/addragandi/.

Kotter, J.P. (1996). Leading Change. Boston: MA Harvard Business School Press. 
Larsen, C.A. (2002). „Municipal size and democracy, a critical analysis of the argument of the proximity based on the case of Denmark“" Scandinavian Political Studies, 25(4), 317-332.

Lög um aðstod vid proskahefta nr. 47/1979.

Lög um fávitahali nr. 18/1936.

Lög um fávitastofnanir nr. 53/1967.

Lög um félagspjónustu sveitarfélaga nr. 40/1991 með áorðnum breytingum 31/1994, 130/1995, 34/1997, 65/2006, 65/2010, 66/2010,152/2010,162/2010,126/2011 og 138/2011.

Lög um málefni fatladra nr. 41/1983.

Lög um málefni fatlaðra nr. 59/1992 með áorðnum breytingum 127/1993, 148/1994, 140/1996, 130/1997, 156/1998, 52/1999, 174/2000, 93/2002, 83/2003, 152/2010, 160/2010, 162/2010, 88/2011, $126 / 2011$ og $178 / 2011$.

Lög um reynshusveitarfélög $\mathrm{nr}$ 82/1994.

Margrét Margeirsdóttir (2001). Fötlun og samfélag. Reykjavík: Háskólaútgáfan.

Norðurping (e.d.). Málefni fatlaðra. Sótt 22. nóvember 2016 af http://www.nordurthing.is/is/thjonusta/ felagsthjonusta/malefni-fatladra

Ómar H. Kristmundsson (2003). Reinventing Government in Iceland. A case study of public management reform. Reykjavík: University of Iceland Press:.

Óskar Dýrmundur Ólafsson (2011). Árangursstjórnun med samstarfi og pátttöku. Lardómur af yfirfarslu verkefna frá ríki til sveitarfélaga. Sótt 3. október 2012 af http://skemman.is/stream/get/1946/10402/ 25899/3/a.2011.7.2.10.pdf.

Persónuvernd (e.d.). Tilkynningar. Sótt 17. nóvember 2012 af http://www.personuvernd.is/tilkynningar/reglur-um-tilkynningarskyldu/.

Ragin, C. (1994). Constructing Social Research. London: Pine Forge Press.

Rubin, A. og Babbie, E. R. (2005). Research Methods for Social Work (5. útg.). Belmont: Thomson Learning.

Samband íslenskra sveitarfélaga (e.d.-a). Félagstjónusta og forvarnarmál. Sótt 5. október 2012 af http:// www.samband.is/media/felagsthjonusta/Heildarsamkomulag-um-tilfaerslu-thjonustu-vid-fatladaendanl.pdf.

Samband íslenskra sveitarfélaga (e.d.-b). Stjórn sambandsins. Sótt 23. október 2012 af http://www.samband.is/um-okkur/stjorn-sambandsins/.

Samband íslenskra sveitarfélaga (e.d.-c). Upplýsingar um sveitarfélög. Sótt 16. nóvember 2012 af http:// www.samband.is/sveitarfelogin/upplysingar-um-sveitarfelog/.

Samband íslenskra sveitarfélaga (e.d.-d). Pjónusta við fatlað fólk. Sótt 16. nóvember 2012 af h htp:// www.samband.is/verkefnin/felagsthjonusta/flutningur-a-malefnum-fatladra/stjornsysla-vegnayfirfaerslunnar/thjonustusvaedi/.

Sameinuðu pjóðirnar (2006). Convention on the Rights of Persons with Disabilities. Sótt 19. október 2012 af http://www.un.org/disabilities/default.asp?id=259.

Sjálfsbjörg landssamband fatlaðra (e.d-a.). Ályktanir. Sótt 27. júlí 2009 af http://www.sjalfsbjorg.is/ index.php?option $=$ com_content\&view $=$ article\&id $=89 \&$ Itemid $=84$.

Sjálfsbjörg landssamband fatlaðra (e.d-b.). Fréttir. Sótt 19. október 2012 af http://www.sjalfsbjorg.is/ index.php/frettir/223-magnus-reynir-nyr-formaeur-a-isafirei.

Stefán Ólafsson (1999). Íslenskea leidin, Almannatryggingar og velferð i fjölpjódlegum samanburdi. Reykjavík: Tryggingastofnun ríkisins og Háskólaútgáfan.

Trygginastofnun (e.d.). Talnaefni. Sótt 18. október 2012 af http://www.tr.is/tryggingastofnun/tryggingastofnun_i_tolum/talnaefni/.

Velferðarráðuneytið (e.d.-a). Sérverkefni. Sótt 10. október 2012 af http://www.velferdarraduneyti.is/ yfirfaersla/spurt-og-svarad/.

Velferðarráđuneytið (e.d.-b). Endurskoðun laga um málefni fatlaðs fólks og félagshjónustu sveitarfélaga. Sótt 22. nóvember 2016 af https://www.velferdarraduneyti.is/frettir-vel/endurskodun-laga-um-malefnifatlads-folks-og-felagsthjonustu-sveitarfelaga

Velferðarráðuneytið (e.d.-c). Framkvamdaáatlun i málefnum fatlaðs fólks. Sótt 22. nóvember 2016 af https://www.velferdarraduneyti.is/framkvaemdaaaetlun/ 